\title{
The effect of composts on the leaching of metals from contaminated soils
}

\author{
R. van Herwijnen ${ }^{1,3,4}$, T. Laverye $^{2}$, S. K. Ouki ${ }^{1}$, A. Al-Tabbaa ${ }^{3}$, \\ M. E. Hodson ${ }^{2}$ \& T. R. Hutchings ${ }^{4}$ \\ ${ }^{I}$ School of Engineering, University of Surrey, Guildford, UK \\ ${ }^{2}$ Department of Soil Science, School of Human and Environmental \\ Science, University of Reading, UK \\ ${ }^{3}$ Department of Engineering, University of Cambridge, UK \\ ${ }^{4}$ Land Regeneration and Urban Greening Group, Forest Research, \\ Farnham, UK
}

\begin{abstract}
Compost is often proposed as a suitable material for the remediation of contaminated brownfield sites intended for soft end-use. In addition to vitalising the soil, it is also supposed to immobilise metals and so break contaminantreceptor pathways and reduce the ecotoxicity of the contaminants. However, some research has demonstrated contradictory effects between composts on metal immobilisation. In our study, five different composts were tested to examine both their metal retention and toxicity reduction capabilities on three different metal contaminated soils. Leaching tests, a plant growth test with Greek cress (Lepidium sativum), an earthworm (Eisenia fetida) survival and condition test and a bacterial toxicity test using Vibrio fischeri were carried out. The batch leaching tests results showed that spent mushroom compost caused an increase in metal concentration in the leachates while LimeX70 compost caused a decrease. The variation in behaviour between different composts for each soil was somewhat random, so a generic conclusion could not be drawn. Toxicity tests showed significant reduction of metal bioavailability and toxicity. Our results also suggest that more rigorous tests should be undertaken to understand the mechanisms involved in metal complexation using different compost types, in order to optimise the use of compost for remediation.

Keywords: compost, heavy metals, toxicity, leaching, remediation.
\end{abstract}




\section{Introduction}

Most large cities in the world have to deal with brownfield sites within their boundaries. Redevelopment of these sites would reduce the need for greenfield development and so protect greenfield land. The UK Environment Agency has estimated that around 20,000 contaminated sites in England and Wales may need treatment [1]. The costs of treatment of these sites can be made more bearable if their remediation is combined with redevelopment. Nevertheless developers generally prefer to choose greenfield land rather than brownfield land because of the high costs of the remediation of contaminated land [1]. This, and the recent increase in landfill costs for contaminated soils, has created a market for low cost alternative remediation techniques. One possible remediation solution for a brownfield site is its transformation into green spaces in the urban environment. Many urban brownfield sites have metal concentrations that significantly exceed the levels that are generally stated as environmentally acceptable and therefore form a potential health risk for humans, animals and plants. The threat of these metals to the environment can be reduced by fixation in the soil itself, thereby lowering the bioavailability and risk of further mobility. A considerable amount of research has been performed on the addition of compost to immobilise metals [2]. Earlier research (van Herwijnen et al. unpublished results) revealed that not all composts immobilise metals in soils. Compost derived from sewage sludge increased leaching of $\mathrm{Cd}$ and $\mathrm{Zn}$ from a polluted soil while compost derived from garden greenwaste immobilised these metals. In order to further investigate this observation we have screened a larger set of composts on their metal immobilising capacity as well as their capability to reduce the toxicity of the contaminated soil. The tested composts in this study were green waste compost, LimeX70 (compost produced from by-products gained through refining sugar), spent mushroom compost, sewage sludge compost and coir compost (composted coconut husks).

In order to get a more general picture of their effect, the composts were tested in combination with three different kinds of metal polluted soil varying from soil with slightly elevated levels of $\mathrm{Cu}$ and $\mathrm{Zn}$ to soil highly contaminated with $\mathrm{Zn}$ or As. The soil-compost mixtures were also tested for their toxicity because mobility of the metals is only weakly related to toxicity due to the different species metals might appear in. This paper presents an overview on whether these compost mobilise or immobilise metals and whether they can reduce toxicity of the polluted soils.

\section{Materials and methods}

\subsection{Materials}

Three contaminated soils, Avonmouth (AM), Devon Great Consols (DGC) and Thamesmead (TM), and five composts, green waste compost (GWC), LimeX70 (LX), spent mushroom compost (SM), sewage sludge compost (SC) and coir compost (CC), were used. An uncontaminated soil, Kettering Loam, was also 
used in some experiments as a control measure. All soils and composts were air dried and sieved to $\leq 4 \mathrm{~mm}$ before any experiments were conducted. The soils and composts were characterised for organic matter content, textural class, $\mathrm{pH}$ and total metal content (As, $\mathrm{Cd}, \mathrm{Cr}, \mathrm{Cu}, \mathrm{Pb}$ and $\mathrm{Zn}$ ).

\subsection{Batch leaching test experiment}

The batch test experiment was conducted following protocols set out by the European Standards Committee [3]. Soil and compost were combined in a mass ratio of 5:1 and placed in an acid washed polyethylene container. Deionised water was added to this mixture in a mass ratio $10: 1$. For each mixture, $500 \mathrm{~cm}^{3}$ of deionised water was mixed with $50 \mathrm{~g}$ of the soil and compost. Four replicates of each mixture were used. The soil/compost suspensions were placed on a rotary shaker set at $10 \mathrm{rpm}$ for 24 hours. After 24 hours the suspensions were filtered first through a $1.2 \mu \mathrm{m}$ filter membrane (Whatman, cellulose nitric membrane) to remove most of the suspended sediment material, and then through a finer $0.45 \mu \mathrm{m}$ filter membrane (Whatman, cellulose nitric membrane). The filtrate was analysed for major elements (Al, As, Ba, Ca, Cd, Cu, K, Mg, $\mathrm{Mn}, \mathrm{Pb}$ and $\mathrm{Zn}$ ) using inductively coupled plasma optical emission spectroscopy (ICP-OES). Results are also compared with leachates of pure compost to ensure observed metal concentrations originate from soil bound metals and not from the composts tested.

\subsection{Ecotoxological experiments}

Only LimeX70, Spent Mushroom and Green Waste of the five original composts were used.

\subsubsection{Growth test using Greek Cress}

The seedling growth and emergence test was conducted using Greek Cress (Lepidium sativum) and followed guidelines set out by the OECD [4]. A soil compost mixture of 5:1 was used, with 4 replicates for each mixture. $50 \mathrm{~g}$ of soil/compost were placed in a $10 \mathrm{~cm}$ diameter pot; to allow a higher retention of water, perlite was placed in the base of each pot. Sixty seeds were added to the surface of the soil in each sample pot. The surface area of the pot was divided into four quarters. 50 seeds were added to three quarters of the soil surface and the last 10 seeds were added to the remaining quarter to be used as a test for survival and germination. The germination test was conducted over a 48 hour period within the watered soils. After 14 days the cress shoots were harvested. The L. sativum stems and leaves of each sample were weighed, dried, ground to a fine powder and digested using nitric acid. Five $\mathrm{cm}^{3}$ of nitric acid were used to digest each sample over 9 hours; 3 hours at $60^{\circ} \mathrm{C}$ and the last 6 hours at $110^{\circ} \mathrm{C}$. The resulting solutions were then analysed for $\mathrm{Al}, \mathrm{As}, \mathrm{Ba}, \mathrm{Cd}, \mathrm{Cr}, \mathrm{Cu}, \mathrm{Pb}$ and $\mathrm{Zn}$ using ICP-OES. 


\subsubsection{Earthworm survival and condition test}

The earthworm survival experiments used a standard earthworm Eisenia fetida and followed protocols modified from the OECD [4]. $500 \mathrm{~g}$ of soil/compost (in a mass ratio of 5:1) was weighed into acid washed plastic containers. The soil and compost mixture was made up to $60 \%$ of the water holding capacity, determined by submerging a known amount of soil (or soil/compost) in water over night, allowing the mixture to drain for 24 hours and then determining the moisture content by loss of mass after drying at $105^{\circ} \mathrm{C}$. Ten clitellate $E$. fetida were added to each container, with $0.5 \mathrm{~g}$ moist of horse manure. After 7 days the worms were counted to determine mortality. Surviving specimens were assessed using a condition index (C.I.), in which scores of 0,1 and 2 are assigned to earthworms which are dead, moribund (flaccid and/or unresponsive to tactile stimulation) and responsive (alive and responsive to tactile stimulation) respectively [5].

\subsubsection{ROTAS test}

The ROTAS test was provided by Cybersense Biosystems Ltd, Oxford, UK. Vibrio fischeri bacteria were rehydrated for 50 minutes using an aqueous salt $(\mathrm{NaCl})$ solution. $1 \mathrm{~cm}^{3}$ of the bacteria suspension was added to each of 24 wells within a test plate. Next $1 \mathrm{~cm}^{3}$ of each sample was added to a well; to each plate a blank (deionised water) and a control of a toxic $\mathrm{Cu}$ solution was included. After 15 minutes the percentage of luminescence emitted by the $V$. fischeri was measured. 100 to $71 \%$ luminescence indicated the sample was not toxic, $70-51 \%$ indicated the sample was moderately toxic and $50-0 \%$ indicated the sample was highly toxic [6].

\subsection{Statistical analysis}

Statistical analysis of the data produced was achieved by an untreated balance structure analysis of variance (ANOVA) test using GenStat [7].

Table 1: Chemical and physical conditions of the used soils.

\begin{tabular}{lccc}
\hline Characteristic & Avonmouth & Devon Great Consols & Thamesmead \\
\hline Available Phosphorus* & 9.0 & 16.6 & 6.4 \\
Available Potassium* & 147 & 29 & 112 \\
Available Magnesium* & 91 & 12 & 53 \\
Sand (\%) & 16 & 94 & 96 \\
Silt (\%) & 50 & 3 & 3 \\
Clay (\%) & 34 & 3 & 1 \\
Textural Class & Silty Clay Loam & Sand & Sand \\
pH & 6.6 & 4.1 & 7.3 \\
Total Cu* & 1274 & 1641 & 137 \\
Total Zn* & 9414 & 47.2 & 339 \\
Total Pb* & 16300 & 189 & 323 \\
Total As* & 191 & 34470 & 12.3 \\
Total Cd* & 239 & 813 & 2.35 \\
\hline
\end{tabular}




\section{Results}

The used composts and soils were analysed for nutrient and metal content (Table 1 and 2). The AM soil was highly contaminated with $\mathrm{Pb}, \mathrm{Zn}$ and $\mathrm{Cu}$, the $\mathrm{DGC}$ soil was highly contaminated with As, and the Thamesmead soil contained elevated levels of $\mathrm{Cu}, \mathrm{Zn}$ and $\mathrm{Pb}$. Amendment of the composts to the soils caused the $\mathrm{pH}$ of the leachates to be between 6.0 and 7.5. A leachate $\mathrm{pH}$ of around 4 was observed only for unamended DGC soil.

The results showed that there was a large variability in leaching effects between different composts. Figure 1 shows the leaching results for $\mathrm{Zn}$ from the three compost amended soils. All compost amendments were significantly different from the control $(\mathrm{p}<0.05)$. While $\mathrm{GWC}, \mathrm{LX}$ and $\mathrm{CC}$ reduced the amount of $\mathrm{Zn}$ leaching from $\mathrm{AM}$ soil, $\mathrm{SC}$ and $\mathrm{SMC}$ increased leaching. Compost amendment to soil from DGC increased the leaching of $\mathrm{Zn}$ for SC and SMC $(p<0.05)$ while the others were not significantly different from the control. Compost amendment to TM soil showed higher leachate concentrations after amendment of GWC, SMC and $\mathrm{CC}(\mathrm{p}<0.05)$, but SC and LX were not significantly different from the control. The increased leaching caused by GWC, $\mathrm{SMC}$ and $\mathrm{CC}$ can be subscribed to $\mathrm{Zn}$ sources in these composts and not from the TM soil.

Leaching of $\mathrm{Cu}$ from AM soil (Table 3) was significantly higher after amendment of GWC, LX, SMC and SC. Similarly, leaching of Cu from TM soil increased for all tested composts but, apart from LX amendment, the increased leaching could be accounted for by $\mathrm{Cu}$ sources in the compost and not from the soil itself. In contrast, the leachate concentration of $\mathrm{Cu}$ in leachates from DGC soil was significantly reduced by the amendment of all composts.

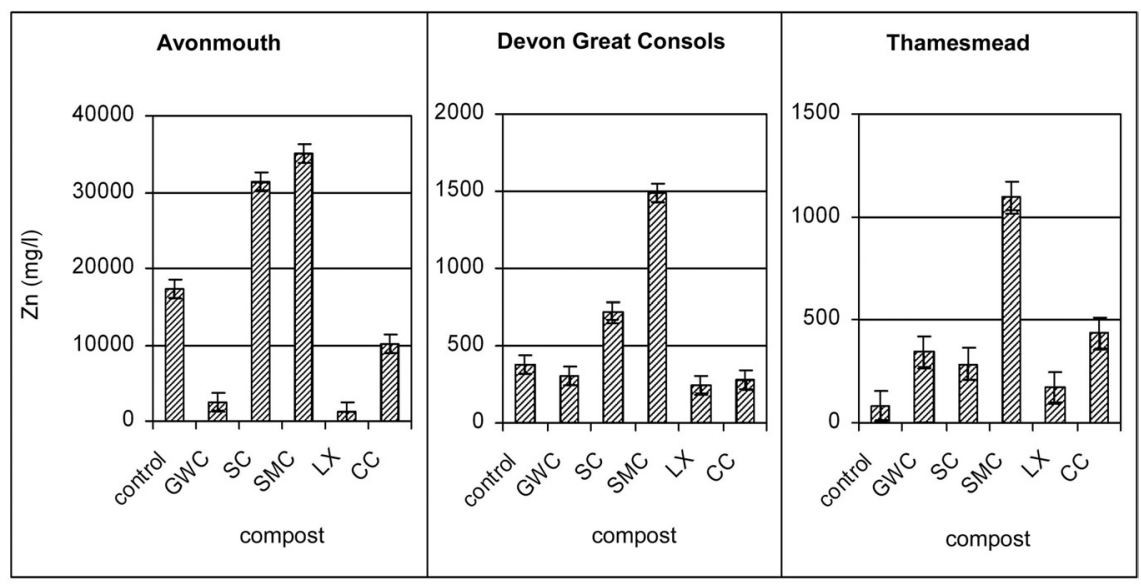

Figure 1: Leaching characteristics of $\mathrm{Zn}$ leaching from metal contaminated soils amended with compost. GWC $=$ Green Waste Compost, $\mathrm{SC}=$ Sewage sludge Compost, SMC = Spent Mushroom Compost, $\mathrm{LX}=\mathrm{Limex} 70, \mathrm{CC}=$ coir compost. Error bars are standard error of the means. 
Table 2: Leachate concentrations $\left(\mathrm{mg} \mathrm{l}^{-1}\right)$ of $\mathrm{Cu}$ and $\mathrm{Pb}$ from compost amended soils.

\begin{tabular}{lllllll}
\hline & Avonmouth & \multicolumn{2}{l}{ Devon Great Consols } & \multicolumn{2}{l}{ Thamesmead } \\
& $\mathrm{Cu}$ & $\mathrm{Pb}$ & $\mathrm{Cu}$ & $\mathrm{Pb}$ & $\mathrm{Cu}$ & $\mathrm{Pb}$ \\
\hline se. & 72.4 & 82.2 & 149.5 & 19.8 & 4.0 & 7.98 \\
\hline Control & 89 & 242 & 1078 & 86.6 & 2.2 & 39.3 \\
$\mathrm{CC}$ & 280 & 275 & $43^{* *}$ & $24.4^{* *}$ & $51.2 * *$ & 40.0 \\
GWC & $382^{* *}$ & 251 & $42^{* *}$ & $21.5^{* *}$ & $46.0^{* *}$ & 36.4 \\
LX & $1140^{* *}$ & 249 & $5^{* *}$ & $12.9^{* *}$ & $48.2^{* *}$ & 16.8 \\
SMC & $2180^{* *}$ & $936^{* *}$ & $274^{* *}$ & 111.7 & $204.4^{* *}$ & 42.8 \\
SC & $559^{* *}$ & 121 & $56^{* *}$ & $11.4^{* *}$ & $29.0^{* *}$ & 13.6 \\
\hline
\end{tabular}

se. $=$ standard error of the means, degree of freedom $=15$.

$* *$ Significant different from the control $(\mathrm{p}<0.05)$
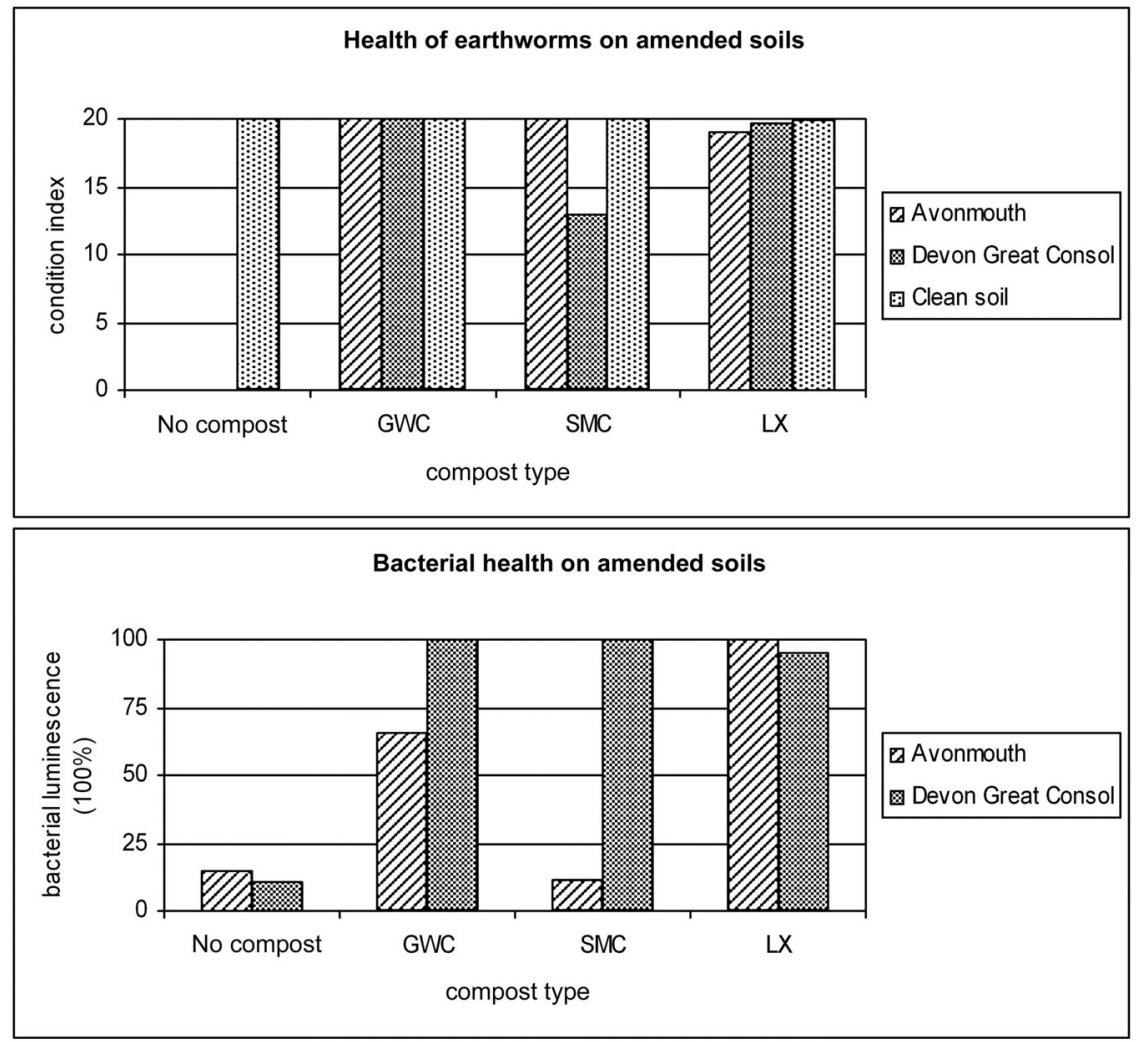

Figure 2: $\quad$ Toxicity of Avonmouth and Devon Great Consols soils amended with different composts. The toxicity was examined with earth worms (Eisenia fetida) $(20=$ not toxic) and the bacterial strain Vibria fischeri $(100=$ not toxic $)$. GWC $=$ Green Waste Compost, $\mathrm{SMC}=$ Spent Mushroom Compost, LX $=$ Limex70. Error bars are standard error of the means. 
The leaching of $\mathrm{Pb}$ from $\mathrm{AM}$ soil (Table 3) was only increased by $\mathrm{SMC}$ and no reduction could be observed by other composts. For the DGC soil, CC, GWC, $\mathrm{LX}$ and $\mathrm{SC}$ reduced the leaching of $\mathrm{Pb}$. For TM soil no effect was observed for the leaching of $\mathrm{Pb}$ by any compost.

Uptake of $\mathrm{Cu}, \mathrm{Pb}$ and $\mathrm{Zn}$ into Greek cress growing on soils amended with GWC, SMC or LX are given in Table 4. For the AM soil, all composts reduced the uptake of $\mathrm{Cu}, \mathrm{Pb}$ and $\mathrm{Zn}$ compared to the control. On the DGC soil no cress grew on unamended soil so no comparison with the control could be made. Nevertheless for all metals LX seemed to cause the highest uptake compared to GWC and SMC. For the TM soil, different trends could be observed for the different metals. Uptake of $\mathrm{Cu}$ was increased by $\mathrm{LX}, \mathrm{Pb}$ uptake was reduced by GWC and uptake of Zn was reduced by GWC and LX but increased by SMC.

Results of ecological tests with bacteria and earthworms are given in Figure 2. The tests with earthworms gave a significant difference between treated and untreated soils for all composts. In most cases the condition of the worms was restored to that of uncontaminated soil. Only SMC amendment to DGC soil failed to restore the toxicity to within $95 \%$ of the clean soil. The results of the bacterial tests (Figure 2) showed that only LX completely reduced the toxicity of AM soil, GWC only partly reduced the toxicity and SMC had no effect at all. The toxicity of the DGC soils for the bacteria was completely reduced by GWC and SMC and almost completely by LX.

Table 3: $\quad$ Metal uptake in Greek cress growing on metal contaminated soil amended with composts. GWC = Green Waste Compost, LX = Lymex 70 and $\mathrm{SMC}=$ Spent Mushroom Compost.

\begin{tabular}{lccccc}
\hline & se. & control & GWC & LX & SMC \\
\cline { 2 - 6 } $\mathrm{Cu}$ & & & & & \\
\hline Avonmouth & 40.0 & 247 & $43^{*}$ & $56^{*}$ & $56^{*}$ \\
Devon Great Consols & 25.2 & - & 42 & $135^{* *}$ & 59 \\
Thamesmead & 12.8 & 28.8 & 22.7 & $76.1^{*}$ & 48.5 \\
\hline & & & & & \\
$\mathrm{Pb}$ & 150.1 & 1625 & $247^{*}$ & $254^{*}$ & $272^{*}$ \\
\hline Avonmouth & 36.6 & - & $179^{* *}$ & $383^{* *}$ & 92 \\
Devon Great Consols & 13.9 & 106.0 & $49.7^{*}$ & 125.7 & 108.4 \\
Thamesmead & & & & & \\
Zn & 175.7 & 3708 & $1218^{*}$ & $623^{*}$ & $869^{*}$ \\
\hline Avonmouth & 25.8 & - & $153^{* *}$ & $171^{* *}$ & $93^{* *}$ \\
Devon Great Consols & 7.12 & 190.9 & $164.0^{*}$ & $158.6^{*}$ & $281.7^{*}$ \\
Thamesmead & & & & & \\
\hline
\end{tabular}

se. $=$ standard error of means

* significant different from control $(\mathrm{p}<0.05)$

** significant different from zero where no control $(\mathrm{p}<0.05)$.

\section{Discussion}

The results presented in this paper differ between the three soils and also between the composts. The leaching results show that GWC, LX and $\mathrm{CC}$ in 
general reduce the leaching of metals from the soils. Only in the case of AM soil is the leaching of $\mathrm{Cu}$ from the soil increased by GWC and LX. SMC and SC in general seem to increase the leaching of soil metals but for these composts contradictory effects were also observed, such as reduced leaching of $\mathrm{Cu}$ by amendment of SMC and SC to the DGC soil. This means that all tested composts have the potential to reduce as well as increase the risk to potential receptors at contaminated sites remediated by compost amendment. Observations of increased leaching are rarely mentioned in literature and usually only mentioned in case of As contamination [2].

The trends observed for metal uptake by Greek cress do not always follow the same trends as observed in the leaching tests. For example, SC generally increased leaching and might indicate a higher bioavailability, but uptake of $\mathrm{Cu}$, $\mathrm{Pb}$ and $\mathrm{Zn}$ on $\mathrm{AM}$ soil was reduced by this compost. However, the GWC, LX and SMC all reduced metal uptake although with some exceptions. Our results indicate that a specific compost may reduce uptake of one metal but increase it for an other, and these effects can be different for different kinds of soil. An explanation for the variety in uptake between metals, composts and soils could be the formation of metal complexes with organic matter from the composts [8], as reported for a mixture of organic household waste compost and wood chips where the concentration of free $\mathrm{Cu}^{2+}$ in the soil water was reduced but the concentration of complexed $\mathrm{Cu}$ was increased [9]. Depending on the type of complex, these complexes could be taken up and transported within the plant. However, only one plant type has been tested in our study and further studies with a variety of plants are recommended to incorporate differences in physiology between plants.

Despite the increased metal leaching and in some cases increased uptake, GWC, SMC and LX efficiently reduced the toxicity to earthworms on AM and DGC soils. For bacteria the same could be observed with exception of SMC that had no effect on AM soil. The improved conditions of the earthworms can be partially ascribed to improved $\mathrm{pH}$ conditions (especially in the case of DGC soil) since the earthworms used prefer a $\mathrm{pH}$ between 5.5 and 8 [10]. The major factor increasing earthworm health is likely to be the increased amount of soil organic matter caused by the addition of compost. Earthworm population size is generally related to soil organic matter content [11]. Compost therefore improves the soil conditions for the worms but the earthworm test results might therefore indicate little about the actual toxicity of the soil mixtures for the worms. Nevertheless the higher performance of the bacteria in compost treated soils in most cases suggests good possibilities to use the tested composts to reduce the toxicity of metal contaminated soils.

\section{Conclusions}

In general, all the tested composts have the ability to improve the soil conditions of a contaminated site. However, negative effects can also be obtained because there is a variety of effects on metal mobility, uptake and toxicity between composts and also between soils they are applied to. Care should therefore be 
taken before applying the materials at operational scale in the field. The results suggest that each time a compost is proposed for remediation of metal contaminated soils it should be tested with the proposed soil in leaching tests, plant tests and toxicity tests to reduce risk of toxic metals reaching potential receptors in the environment. Our results also suggest that more rigorous tests should be undertaken to understand the mechanisms involved in metal complexation using different compost types, in order to optimise the use of compost as a remediation technique.

\section{Acknowledgements}

The authors are grateful to the following people who have generously supplied materials for the research or assisted with the practical work: Adrian Nash from Halcrow who provided the contaminated soil and also arranged the transport; Andy Johnson and Andrew Weeks from Thames Water - Terra Eco Systems for supplying the composted sewage sludge. The financial contribution from the EPSRC, who funded part of this work under the SUBR:IM consortium (Grant GR/S148809/01) and the NERC MSc studentship for Tim Laverye were grateful acknowledged.

\section{References}

[1] Environment-Agency, The state of soils in England and Wales. Environment Agency, Bristol. 2004.

[2] Gadepalle, V. P., Ouki, S. K., van Herwijnen, R. \& Hutchings, T., Immobilisation of heavy metals in soil using natural and waste materials for vegetation establishment on contaminated sites. Soil Sed. Contam., pp. in press.

[3] BSI, Characterisation of waste - Leaching - Compliance test for leaching of granular waste materials and sludges. BS En 12457: Part 2: One stage batch test at a liquid to solid ratio of $10 \mathrm{l} / \mathrm{kg}$ for materials with particle size below $4 \mathrm{~mm}$ (without or with size reduction). British Standards Institution, London. 2002.

[4] OECD, OECD Guideline for testing of chemicals -208- "Terrestrial Plants, Growth Test", vol. 208. OECD - Organisation for Economic Cooperation and Development, Paris. 1984.

[5] Langdon, C. J., Piearce, T. G., Meharg, A. A. \& Semple, K. T., Survival and Behaviour of the Earthworms Lumbricus rubellus and Dendrodrilus rubidus from Arsenate-Contaminated and Non-Contaminated Sites. Soil Biol. Biochem. 33, pp. 1239-1244. 2001.

[6] Loureiro, S., Ferreira, A. L. G., Soares, A. M. M. \& Nogueira, A. J. A., Evaluation of the toxicity of two soils from Jales Mine (Portugal) using aquatic bioassays. Chemosphere 61, pp. 168-177. 2005.

[7] Genstat, The Guide to GenStat Release 8.1 Part 2: Statistics. In R. W. Payne (ed.), 8.1 ed. Lawes Agricultural Trust (Rothamsted Experimental Station) - VSN International, Oxford, 2005. 
[8] da Silva, J. \& Oliveira, C. J. S., Metal ion complexation properties of fulvic acids extracted from composted sewage sludge as compared to a soil fulvic acid. Water Res. 36, pp. 3404-3409. 2002.

[9] Kiikkila, O., Perkiomaki, J., Barnette, M., Derome, J., Pennanen, T., Tulisalo, E. \& Fritze, H., In situ bioremediation through mulching of soil polluted by a copper-nickel smelter. J. Environ. Qual. 30, pp. 1134-1143. 2001.

[10] Kaplan, D. L., Hartenstein, R., Neuhauser, E. F. \& Malecki, M. R., Physiochemical Requirements in the Environment of the Earthworm Eisenia foetida. Soil Biol. Biochem. 12, pp. 347-352. 1980.

[11] Edwards, C. A. \& Bohlen, P. J., Biology and Ecology of Earthworms, 3rd ed. Chapman and Hall, London. 1996. 